\title{
Determinants of Outreach Performance of Microfinance Institutions in Pakistan
}

\author{
Muhammad Saad \\ School of Economics, Finance and Banking \\ University Utara Malaysia, Malaysia \\ siddiquie011@gmail.com
}

\author{
Hasniza Mohd Taib, PhD \\ School of Economics, Finance and Banking \\ University Utara Malaysia, Malaysia
}

\author{
Abul Bashar Bhuiyan, PhD \\ Faculty of Business and Accountancy (FBA) \\ University of Selangor, Malaysia
}

\begin{abstract}
Microfinance institutions (MFIs) are developed to provide financial services to poor people usually ignored by commercialized institutions. Their main purpose is to increase outreach both in terms of depth and breadth, by providing small loans and reaching maximum number of poor people. This study aims to study the factors that influence the outreach performance of MFIs in Pakistan. By using random effect regression, factors that influence the depth and breadth of outreach were determined. Return on asset and firm size effect both the depth and breadth of outreach, whereas, portfolio at risk greater than 30 days impact the breadth of outreach only. Additionally, operating expense ratio does not influence the outreach performance of $\mathrm{MFI}$.
\end{abstract}

Keywords: outreach, performance, depth, breadth, microfinance, microfinance institutions

\section{Introduction}

Microfinance, besides a financial solution, is the major contributor for the alleviation of poverty and long-term economic growth (CGAP, 2004; Manos \& Yaron, 2009), as long-term development can be achieved by financial inclusion of the poor (W. Rahman \& Luo, 2011). Various associations can be microfinance provider, which include credit unions, financial intermediaries, banks and non-profit organizations. They are known as microfinance institutions (MFIs) (Muwamba, 2012; Olasupo et al., 2014). These organizations differ from each other by organization focus and clientele but does restrict to these only.

There are two major goals for microfinance institutions (Chenuos et al., 2014). The first goal of MFI is to contribute to development by approaching a maximum number of clients and reaching the poorest (Nanayakkara, 2012). The second important goal for MFIs is to reach poor clients by achieving financial sustainability. According to Olasupo et al. (2014), MFIs management should be efficient in promoting both the objectives. Woller et al. (1999) also introduced two approaches known as "the Institutionist approach" and "the Welfarist Approach.” Institutionist approach sticks with financial sustainability of institutions and poverty alleviation simultaneously whereas, Welfarists approach emphasized on reaching poor clients by using subsidized funds.

Microfinance promises to develop its customers and provide capital to overcome poverty. Therefore, greater understanding on the MFIs sustainability is essential for the well-being of individuals and business (Muwamba, 2012). The importance of MFIs in poverty alleviation and contribution in the overall economy attracts researchers to study the sustainability of MFIs. Several studies have

The current issue and full text archive of this journal is available at www.jraspublications.org/index.php/JRAS/issue/archive

Journal of Research in Administrative Sciences

VI(II), 19-23, ISSN: 2664-2433 attempted to investigate the factors that influence the sustainability of MFIs. However, the factors identified and level of significance of these factors were vary (see, for example Bhanot et al., 2015; Quayes, 2012). Additionally, existing literature has emphasized mainly on the financial sustainability (Adongo \& Stork, 2005; Rahman \& Mazlan, 2014; Tehulu, 2013) and ignored the social aspect of outreach. There is a scarce of literature on determining the factors that influence the outreach of MFIs. This study is an attempt to cover the literature gap by focusing mainly on the outreach. An unbalanced panel data of 37 MFIs from Pakistan including 9 banks, 4 rural support programs, and 24 microfinance firms, for a period of 2011-2015 is used to determine the factors that influence the outreach performance of MFIs in Pakistan.

The remaining paper follows the following pattern; literature review in section 2, variable selection in section 3, data and methodology in section 4, empirical results in section 5, conclusion in section 6 and references in the last section.

\section{Literature Review}

Since the inception of civilization, poverty has been an issue for humanity and battle for the survival of human exists. Among several other factors leading to poverty, limited availability of credit facilities to the poor people is also one of the major reasons for poverty (Tehulu, 2013). Poor people of the society lack access to any credit facility as they were unable to offer collaterals and securities against credits. Formal financial institutions provide facilities only for new companies and business, to begin and expand their operations, who offer collaterals and securities against credit. Poor people of the society also need various monetary services, including loan facilities, savings, insurance, and funds transfer 
Muhammad Saad, Hasniza Mohd Taib, PhD Abul Bashar Bhuiyan, PhD

(CGAP, 2004). Microfinance institutions became the solution to poverty problem by providing credit facilities to poor people for starting a small business (Tehulu, 2013). These financial institutions were not restricted to provide loans/credit facilities only, but include other services such as insurance, education, health, social awareness and savings/deposits. Thus microfinance, by empowering poor, was a concept of poverty reduction (Manos \& Yaron, 2009).

\section{History of Microfinance Institutions}

Microfinance laid its footsteps several hundred years ago. In the beginning, different forms of loans/credit facilities for small farmers and poor people were provided by individuals, donors, charity associations and informal lenders in unstructured form and were commonly known as informal microfinance institutions. In the early 1970s, these financial intermediaries were replaced by microfinance banks and agencies which are now known as formal microfinance institutions. Few examples of formal and informal MFIs in different countries are discussed in the section below.

\section{Informal Microfinance Institutions}

Since the 15th century, informal MFIs in Nigeria have been helping poor people of the society. In the $16^{\text {th }}$ century, informal finance laid its roots in different parts of Europe. In Ireland, the first loan fund for poor was started during 1720 followed by a slow growth until the transformation of charities and donation funds as financial intermediaries. In 1823, these financial intermediaries started accepting deposits and charged interest rates for the first times on the credits provided by them (Seibel, 2003). Similarly, in Germany, during 1847, Raiffeisen and Schulze-Delitzsch established rural and urban savings and credit cooperatives to help poor (Seibel, 2005). All these urban and rural credit associations were regularized under the German Cooperative Act 1889. According to Murdoch, the total number of poor people served by these cooperatives in 1910 was increased to 1.4 million (Morduch, 1999).

In Asia, a different type of informal credit systems was founded, some were as old as 2200 years, including Paluwagan (Philippines), Artisan (Indonesia), Chit funds (India) and Hui (China). In Asian sub-continent ${ }^{1}$, different types of informal financial intermediaries exist from $13^{\text {th }}$ to the $18^{\text {th }}$ century which was later replaced by Raiffeisen model in 1892. Later in 1912, to support the rural selfhelp groups, some changes were made in Co-operative Societies Act. In 1919, different provinces in the Asian sub-continent were given authority to implement their cooperative laws which were later withdrawn in 1954 on the endorsements of Cooperative law committee and All India Rural Credit committees (Seibel, 2005). In the 1950s, governing bodies, as well as international donors in different Asian countries, started subsidizing loan to farmers (Rogaly, 1996).

In Pakistan, informal funding by the government begun in 1953 through village AID package (a five-year plan) which was extended until 1962. In 1961, Agriculture Development Bank (now Zarai Taraqiati Bank) was established to reduce poverty by providing subsidized funds and small loans to the farmers (Farooq \& Khan, 2014). From the 1980s to 1990 s, several rural support programs were started to overcome poverty level through subsidized funds. These include Orangi pilot project (1987), Agha Khan rural support program (ARSP) (currently First microfinance bank), National rural support program (NRSP) (1991) and Sarhad rural support program (SRSP) (1989) (Ahmad, 2011).

\section{Formal Microfinance Institutions}

Formal microfinance institutions (MFIs) were established during the 1970s. Bank Dagan Bali Indonesia is currently one of the biggest MFIs and was started during the year 1970. Later in 1973, the first microloan for poor was disbursed by ACCION in Brazil which was followed by Muhammad Yunus first loan in Bangladesh. In 1972, Muhammad Yunus from Bangladesh lent a small amount of \$27 to 42 people in his country which later formalized as Grameen Bank. The revolution in microfinance industry was observed after the year 1974 when Muhammad Younus established Grameen Bank in Bangladesh. In Pakistan, Khushali Bank is established in year 2000 under a development program for microfinance sector with objective to help poor by providing subsidized loans and credits (Rauf \& Mahmood, 2009).

During the early days of 2011, microfinance achieved a milestone of reaching more than 200 million poor across the globe (Maes \& Reed, 2012). According to the data reported to MIX market in 2014, the total gross loan portfolio of MFIs has reached USD 78 billion. Therefore, microfinance was considered as a best available tool for sustainable development and growth. This was also endorsed as Muhammad Younus received Nobel Prize in 2007 for their contribution to reducing poverty through microfinance.

\section{Outreach Performance}

MFIs can play an important role in developing countries by providing credit to poor people who do not have access to formal credit which usually requires collateral. Access to credit is welfare enhancing, and allocation of credit to the poor is an integral function of MFIs, therefore, outreach is an important measure of success (Quayes, 2015)

Outreach is measured by the depth and breadth of essential services of microfinance institutions such as credit provision, savings mobilization, micro insurance, money transfer, and payment services (Rao, 2014). It measures how well an MFI has reached its target clients and fulfill the financial services demand of the clients (Yaron, 1994). Yaron (1994) and Okumu (2007) describe outreach as MFI efforts to provide service to poor people of the society formally unserved by other financial institutions. They further describe that outreach is categorized as breadth and depth, where the breadth of outreach represents the number of poor clients reached. The depth of outreach represents the socioeconomic impact which MFI services have on the target customers. Furthermore, Rhyne (1998) also defines outreach as a measure of its depth and breadth. 2.2.1 Depth and breadth of Outreach

The depth of outreach (DO) may be defined as the "poverty level of clients served by MFI" (Rao, 2014; Rauf \& Mahmood, 2009). The DO narrates the line of poverty, or the extent poor does not have access to regulated financial institutions. The proxy for DO is the average size of loan because other indicators of DO are usually expensive to collect. In recently published studies, DO was measured by average loan balance/size per borrower (Bhanot et al., 2015; Nanayakkara, 2012; Okumu, 2007).

The breadth of outreach refers to "the scale of operations of an MFI" (Rao, 2014). Several studies have used number of active borrowers as a measure of the breadth of outreach (Kinde, 2012; Rai \& Rai, 2012; Rauf \& Mahmood, 2009). Results of Louis and Baesens (2013) shows that BO are positively related whereas the DO has a weaker impact on MFI profitability. Similarly, Rai and Rai (2012) also found that breadth influence OSS of MFI.

The concept of depth and breadth is widely used in microfinance literature as a measure of MFI regarding outreach (Kar, 2013; Quayes, 2015; Vanroose \& D'Espallier, 2013). Schreiner (2001) proposes a six-dimension approach for measuring the outreach. These dimensions were: 1) the outreach depth is measured as average loan size; 2) worth to users regarding dropout rate; 3 ) the cost to users regarding interest rate charged; 4) the length of outreach regarding financial performance, 6) width regarding number and percentage change of clients served, and 7) the scope of outreach regarding insurance, savings, and types of loans. 
Muhammad Saad, Hasniza Mohd Taib, PhD Dr. Abul Bashar Bhuiyan, PhD

Table 1. Comparison between Schreiner and Yaron

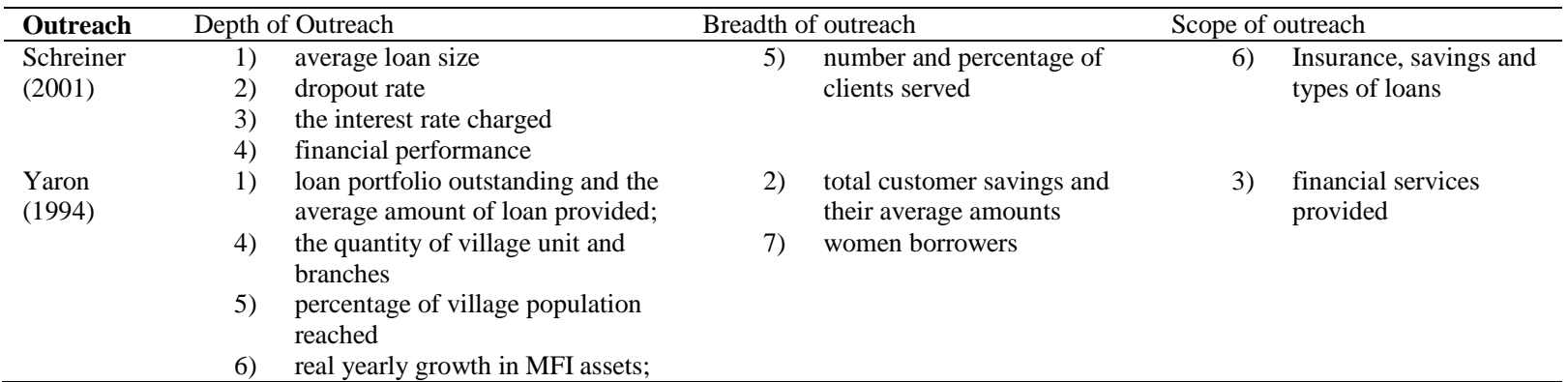

On the other hand, Yaron (1994) suggests seven measures of outreach including: 1) loan portfolio outstanding and the average amount of loan provided; 2) total customer savings and their average amounts; 3) financial services provided; 4) the quantity of village unit and branches; 5) percentage of village population reached; 6) real yearly growth in MFI assets; and 7) women borrowers. The comparison between Schreiner and Yaron shown in Table 1 implies that outreach is measured as depth, breadth and scope of outreach. According to Mersland and Strøm (2010), for an MFI, the risk associated with variation in the average size of the loan is unpredictable. Results describe that when loan size is small, MFI will be more cost effective. As average loan size increases, it increases the average operational cost thus increasing the average profit of an MFI. However, Kumar Kar (2011) found that MFI should be careful in increasing the size of the loan as the risk associated with the loan also increases. Thus, the optimal size of the loan should be decided carefully. The increase in loan size also enhance the possibility of loan default and affects MFI profitability. MFIs with smaller ALPB usually reach a large number of poor clients which shows a better depth of outreach. Similarly, MFIs whose average loan balance per borrower is large tend to reach less poor clients thus resulting in a mission drift (Kar, 2013).

Cull (2011) found that when MFIs are profit oriented, their client outreach decrease. Close monitoring and onsite supervision also increase average loan size, thus decreasing outreach. On the other

Table 2. Dependent and Independent Variables

\begin{tabular}{|c|c|c|c|}
\hline & Variabes & Measurement & Source \\
\hline \multirow[t]{2}{*}{$\begin{array}{l}\text { Dependent } \\
\text { variable }\end{array}$} & Depth of outreach & $\begin{array}{c}\text { ALPB =gross loan portfolio / number of active } \\
\text { borrowers }\end{array}$ & $\begin{array}{c}\text { Daher and Le Saout (2015), Janda and } \\
\text { Turbat (2013) }\end{array}$ \\
\hline & Breadth of outreach & $\mathrm{NAB}=$ total number of active borrowers & Crawford et al. (2014), Quayes (2015) \\
\hline \multirow[t]{4}{*}{$\begin{array}{c}\text { Indepndent } \\
\text { variable }\end{array}$} & Return on asset & $\begin{array}{c}\mathrm{ROA}=\text { (net operating income }-\operatorname{tax}) / \text { average } \\
\text { equity }\end{array}$ & Zaigham and Asghar (2011), \\
\hline & $\begin{array}{l}\text { Portflio at risk greater } \\
\text { than } 30 \text { days }\end{array}$ & $\begin{array}{c}\text { PAR=unpaid balance of past due loans with } \\
\text { overdue greater than } 30 \text { days / gross outstanding } \\
\text { lona portfolio }\end{array}$ & Rai and Rai (2012); Tehulu (2013) \\
\hline & Operating expense ratio & $\begin{array}{c}\text { OER=total operating expense / average } \\
\text { outstanding portfolio }\end{array}$ & $\begin{array}{l}\text { Louis et al. (2013); Tucker and Miles } \\
\text { (2004) }\end{array}$ \\
\hline & size of MFI & SIZE=total assets of MFI & Adhikary and Papachristou (2014) \\
\hline
\end{tabular}

\section{Methodology}

The purpose of this suty is to determine the factors that influence outreach performance. The following models have been specified for this purpose

$$
\begin{aligned}
& A L P B_{i t}=\alpha_{0}+\beta_{1} R O A_{i t}+\beta_{3} P A R_{i t}+\beta_{5} O E R_{i t}+\beta_{6} T A_{i t}+ \\
& \varepsilon_{i t} \quad(1) \\
& N A B_{i t}=\alpha_{0}+\beta_{1} R O A_{i t}+\beta_{3} P A R_{i t}+\beta_{5} O E R_{i t}+\beta_{6} T A_{i t}+ \\
& \varepsilon_{i t}
\end{aligned}
$$

Where $i$ refers to microfinance institutions; $t$ refers to year, ALPB refers to average loan balance per borrower in equation (1) and $N A B$ represents number of active borrowers in equation (2). Additionally, $R O A$ refers to return on assets, $P A R$ represents portfolio at risk $>30$ days, $O E R$ refers to operating expense ratio, and $T A$ measure size of MFI and $\varepsilon$ is the error term in both equations (1) and (2).

\section{Empirical Results}

side, Adhikary and Papachristou (2014) study across South Asian countries found that outreach and MFI financial performance is related positively. Other studies also found the positive correlation of outreach with financial performance (Kipesha \& Zhang, 2013; Louis \& Baesens, 2013).

\section{Data and Variable}

Data

The study use data obtained from the annual reports of Pakistan microfinance review, that provides consolidated data for the MFI sector in Pakistan. An unbalanced panel data sample of 37 MFIs operating in Pakistan from the year 2011-2015 which consists of 162 observations is obtained for this study. These MFIs include 9 banks, 4 rural support programs, and 24 microfinance institutions. 3.2 Variables

Tabel 2 shows the list of depndent and indepnedent variables ued in this study. The study used two measures of outreach perfromance as dependent variable. The first measure is depth apporximated by average loan balance per borrower (ALPB). Increase in ALPB represents a low poverty outreach, which represents negative outreach performance. Additionally, second dependent variable is breadth of outreach, measured by number of active borrowers. An increase in number of active borrowers indicates a positive outreach performance. Additionally, the independent variables used in this study and their measurements are mentioned in the table 2 . 
Muhammad Saad, Hasniza Mohd Taib, PhD Abul Bashar Bhuiyan, PhD

Additionally, this indicates the lack of close monitoring and supervision of loan portfolio. Although, mean value of MFI PAR is 0.046, which is relatively better but still MFIs in Pakistan need to manage their loan portfolio. Higher OER value shows that cost for loan is high. Additionally, it shows that MFIs are unable to manage their administrative and operating cost which affect their profitability. OER has a mean value of 0.176 , and maximum value of 1.28 indicating higher operating expense ratio. Size of MFI measured by using its total assets and MFIs in Pakistan has an average total asset of PKR 2.8 billion.

Table 3. Descriptive statistics

\begin{tabular}{lllll}
\hline Variable & Obs. & Mean & Min & Max \\
\hline ALPB & 162 & 20511.79 & 3695.09 & 122810 \\
NAB & 162 & 80790.65 & 26 & 589668 \\
ROA & 162 & 0.022 & -0.585 & 0.244 \\
PAR & 162 & 0.046 & 0 & 0.834 \\
OER & 162 & 0.176 & 0.018 & 1.282 \\
SIZE & 162 & 2809322 & 10295 & 26696346 \\
\hline
\end{tabular}

Before using regression analysis, several diagnostics including multicollinearity, homoskedasticity and autocorrelation are performed to check for the best linear unbiased estimator assumptions. Results does not find any evidence of correlation among the dependent and explanatory variables. Additionally, the problem of heteroskedasticity and autocorrelation found in the data are removed using white cross-section in regression analysis.

Hausman test is performed to check among the fixed effect and random effect model. Results suggest the random effect model for regression analysis is to be used for this study. Table 4 present the results for random effect regression using white cross-section model. The set of explanatory variables presented in equation (1) and (2) are regressed on ALPB and NAB. The variables ALPB, $\mathrm{NAB}$ and total asset are subjected to natural logarithm to improve the model goodness of fit and avoid simultaneity bias (Nasrin et al., 2018).

ROA negatively influence outreach of MFIs approximated by ALPB. Results implies that increase in value of ROA results in the decrease in average loan balance per borrower. The coefficient value of ROA is -1.598 and is significant at 1 percent. This implies that as MFIs tend to focus on increased profitability this may be achieved when they decrease the average loan balance per borrower or increase their depth of outreach. Findings of this study are in accordance with Kipesha and Zhang (2013) for MFIs in East Africa. Additionally, ROA has a positive significant relationship with NAB with coefficient value of 3.094 and at a significance level of 10 percent. This implies that as MFIs become profitable they tend to increase their client portfolio and target large number of poor borrowers.

Portfolio quality measured by PAR has negative insignificant impact on ALPB. This implies that portfolio at risk does not influence the outreach of MFIs. Furthermore, the relationship between PAR and NAB is statistically negatively significant. PAR has coefficient value of -2.99 and is significant at 10 percent. Result suggest that as loan portfolio quality is highly related with the outreach of MFI. MFIs should be prudent in increase their customer portfolio as these portfolios are not backed by any security. Poor management of loans may be one of the reasons for the increase in bad loans.

Table 4. Random effect model (White Cross-section)

\begin{tabular}{|c|c|c|c|c|}
\hline \multicolumn{2}{|r|}{ ALPB } & NAB & & \\
\hline Variable & Coefficient & Prob. & Coefficient & Prob. \\
\hline $\mathrm{C}$ & 7.201 & 0 & -0.131 & 0.740 \\
\hline ROA & $-1.598^{*}$ & 0.006 & $3.094 * * *$ & 0.053 \\
\hline PAR & -0.307 & 0.355 & $-2.990 * * *$ & 0.053 \\
\hline OER & -0.218 & 0.486 & 0.673 & 0.179 \\
\hline $\begin{array}{l}\text { LNTA } \\
\text { R- }\end{array}$ & $0.190 *$ & 0 & $\begin{array}{l}0.751^{*} \\
64.52 \%\end{array}$ & 0 \\
\hline $\begin{array}{l}\text { squared } \\
\text { F value }\end{array}$ & $\begin{array}{l}34.80 \% \\
20.95 *\end{array}$ & & $71.39 *$ & \\
\hline
\end{tabular}

Note: *,*** represents significance at 1 percent and 10 percent Size of MFI is significantly related to average loan balance per borrower. The coefficient value for size of MFI is 0.19 and is statistically significant at 1 percent. the results are consistent with Khan and Shaorong (2016) for MFIs in South Asia. This implies that as MFIs size increase they tend to increase loan size and focus less poor or relatively wealthier clients. This implies that large MFIs deviate from their original mission of reaching the maximum number of poor people. Furthermore, size of MFI is also positive related to number of active borrowers. Result suggest that large MFI are more focused towards reaching the large customer base by increasing their number of borrowers. Additionally, it indicates that large MFIs usually perform better in terms of outreach. Moreover, regression results suggest that OER does not influence the outreach performance when measured by ALPB and NAB. This result implies that OER does not impact outreach performance of MFI.

\section{Summary of Findings and Recommendations}

The study has contributed to existing literature as it is among few of the pioneer studies to identify the factors that influence the outreach performance of MFIs. This study identified the impact of ROA, PAR, OER and TA on the outreach performance by using unbalanced panel data of 37 MFIs from the year 2011-2015. Findings of the current study are important for the policy makers and microfinance researchers.

Results of regression analysis suggest that outreach of MFI approximated by ALPB is negatively influenced by ROA and positively influenced by size of MFI. Additionally, PAR, and OER does not influence depth of outreach. Large MFIs tend to focus on large loan size which shows deviation of MFIs from its original mission. On the other hand, results suggest that profitable MFIs usually focus on very poor customers.

The results of the model measured by equation (2) where outreach performance is measured by NAB present different results. The relationship between ROA and NAB shows that profitable MFIs reinvest their profit by increasing their loan portfolio and reach maximum number of poor people. Results indicate that profitability positively influence the outreach performance. Additionally, the portfolio at risk negatively influence the outreach performance of MFI. MFIs with greater asset proportion or with large size also strongly positively influence the outreach performance of MFIs. Moreover, results suggest that OER does not influence the breadth and depth of MFI outreach.

\section{References}

i. Adhikary, S., \& Papachristou, G. (2014). Is there a trade-off between financial performance and outreach in south asian Microfinance institutions? The Journal of Developing Areas, 48(4), 381-402.

ii. Adongo, J., \& Stork, C. (2005). Factors influencing the financial sustainability of selected microfinance institutions in Namibia: Namibian Economic Policy Research Unit.

iii. Ahmad, U. (2011). Efficiency Analysis of Micro-finance Institutions in Pakistan.

iv. Bhanot, D., Bapat, V., \& Connelly, J. (2015). Sustainability index of micro finance institutions (MFIs) and contributory factors. International Journal of Social Economics, 42(4).

v. CGAP. (2004). Key Principles of Microfinance. Retrieved from http://www.cgap.org/publications/key-principles-microfinance

vi. Chenuos, N. K., Mohamed, A., \& Bitok, S. K. (2014). Effects of Corporate Governance on Micro Finance Institutions Financial Sustainability in Kenya. European Journal of Business and Management, 6(30), 71-81.

vii. Crawford, A., Skully, M. T., \& Tripe, D. W. (2014). Are profitable microfinance programs less efficient at reaching the poor? A case study in Cambodia. A Case Study in Cambodia (February 25, 2014).

viii. Cull, M. (2011). Does regulatory supervision curtail microfinance profitability and outreach? World development, 39(6), 949-965. 
Muhammad Saad, Hasniza Mohd Taib, PhD Abul Bashar Bhuiyan, PhD

ix. Daher, L., \& Le Saout, E. (2015). The Determinants of the Financial Performance of Microfinance Institutions: Impact of the Global Financial Crisis. Strategic Change, 24(2), 131-148.

x. Farooq, M., \& Khan, Z. (2014). The Social and Financial Performance of Conventional and Islamic Microfinance Institutions in Pakistan: Al-Idah.

xi. Janda, K., \& Turbat, B. (2013). Determinants of the financial performance of microfinance institutions in Central Asia. PostCommunist Economies, 25(4), 557-568.

xii. Kar, A. K. (2013). Mission drift in microfinance: are the concerns really worrying? Recent cross-country results. International Review of Applied Economics, 27(1), 44-60.

xiii. Khan, W., \& Shaorong, S. (2016). Microfinance Mission of Poverty Alleviation: Empirical Evidence from South Asia. Sarhad Journal of Management Sciences, 2(01), 1-8.

xiv. Kinde, B. A. (2012). Financial sustainability of microfinance institutions (MFIs) in Ethiopia. European Journal of Business and Management, 4(15), 1-10.

xv. Kipesha, E. F., \& Zhang, X. (2013). Sustainability, Profitability and Outreach Tradeoffs: Evidences from Microfinance Institutions in East Africa. European Journal of Business and Management, 5(8), 136-148.

xvi. Kumar Kar, A. (2011). Microfinance institutions: A crosscountry empirical investigation of outreach and sustainability. Journal of Small Business \& Entrepreneurship, 24(3), 427-446.

xvii. Louis, P., \& Baesens, B. (2013). Do for-profit microfinance institutions achieve better financial efficiency and social impact? A generalised estimating equations panel data approach. Journal of Development Effectiveness, 5(3), 359-380.

xviii. Louis, P., Seret, A., \& Baesens, B. (2013). Financial efficiency and social impact of microfinance institutions using selforganizing maps. World development, 46, 197-210.

xix. Maes, J. P., \& Reed, L. R. (2012). State of the microcredit summit campaign report 2012. Microcredit Summit Campaign.

xx. Manos, R., \& Yaron, J. (2009). Key issues in assessing the performance of microfinance institutions. Canadian Journal of Development Studies/Revue canadienne d'études du développement, 29(1-2), 101-122.

xxi. Mersland, R., \& Strøm, R. Ø. (2010). Microfinance mission drift? World development, 38(1), 28-36.

xxii. Morduch, J. (1999). The microfinance promise. Journal of economic literature, 1569-1614.

xxiii. Muwamba, D. (2012). Sustainability of MFIs through Governance Mechanisms: A cross-Country Analysis of Regulation on Outreach and Operational Self Sufficiency.

xxiv. Nanayakkara, G. (2012). Measuring the performance of microfinancing institutions: a new approach. South Asia Economic Journal, 13(1), 85-104.

xxv. Nasrin, S., Rasiah, R., Baskaran, A., \& Masud, M. M. (2018). What determines the financial performance of microfinance institutions in Bangladesh? a panel data analysis. Quality \& Quantity, 52(3), 1409-1422.

xxvi. Okumu, L. J. (2007). The microfinance industry in Uganda: sustainability, outreach and regulation. Stellenbosch: University of Stellenbosch.

xxvii. Olasupo, M. A., Afolami, C. A., \& Shittu, A. M. (2014). Outreach and Financial Sustainability of Microfinance Banks in Southwest Nigeria. International Journal of Economics and Finance, 6(2), p25.

xxviii. Quayes, S. (2012). Depth of outreach and financial sustainability of microfinance institutions. Applied Economics, 44(26), 3421 3433.

xxix. Quayes, S. (2015). Outreach and performance of microfinance institutions: a panel analysis. Applied Economics, 47(18), 19091925.

xxx. Rahman, \& Mazlan. (2014). Determinants of Operational Efficiency of Microfinance Institutions in Bangladesh. Asian Social Science, 10(22), p322. xxxi. Rahman, W., \& Luo, J. (2011). Comparison of microfinance models in China and Bangladesh: the implications for institutional sustainability.

xxxii. Rai, A. K., \& Rai, S. (2012). Factors affecting financial sustainability of microfinance institutions. Journal of Economics and Sustainable Development, 3(6), 1-9.

xxxiii. Rao, K. R. M. (2014). Concepts And Measures of Outreach and Sustainability in Microfinance Institutions: A comprehensive literature review. Research Journal of Finance and Accounting, 5(21), 41-48.

xxxiv. Rauf, S. A., \& Mahmood, T. (2009). Growth and performance of microfinance in Pakistan. Pakistan Economic and Social Review, 99-122.

xxxv. Rhyne, E. (1998). The yin and yang of microfinance: Reaching the poor and sustainability. MicroBanking Bulletin, 2(1), 6-8.

xxxvi. Rogaly, B. (1996). Micro-finance evangelism,'destitute women', and the hard selling of a new anti-poverty formula. Development in practice, $6(2), 100-112$.

xxxvii. Schreiner, M. (2001). Seven aspects of loan size. Journal of Microfinance/ESR Review, 3(2), 27-47.

xxxviii. Seibel, H. D. (2003). History matters in microfinance. Retrieved from

xxxix. Seibel, H. D. (2005). Does history matter? The old and the new world of microfinance in Europe and Asia. Retrieved from

xl. Tehulu, T. A. (2013). Determinants of Financial Sustainability of Microfinance Institutions in East Africa. European Journal of Business and Management, 5(17), 152-158.

xli. Tucker, M., \& Miles, G. (2004). Financial performance of microfinance institutions: A comparison to performance of regional commercial banks by geographic regions. Journal of Microfinance/ESR Review, 6(1), 41-54.

xlii. Vanroose, A., \& D'Espallier, B. (2013). Do microfinance institutions accomplish their mission? Evidence from the relationship between traditional financial sector development and microfinance institutions' outreach and performance. Applied Economics, 45(15), 1965-1982.

xliii. Woller, G., Dunford, C., \& Woodworth, W. (1999). Where to microfinance. International Journal of Economic Development, 1(1), 29-64

xliv. Yaron, J. (1994). What makes rural finance institutions successful? The World Bank Research Observer, 9(1), 49-70.

xlv. Zaigham, R., \& Asghar, N. (2011). Sustainability of Micro Finance Banks: A comparative Case study from Pakistan. 